$\begin{array}{ll}\text { Dikumpulkan } & \text { Februari } 2018 \\ \text { Direvisi } & \text { : Juli } 2018 \\ \text { Diterima } & \text { : September } 2018 \\ \text { DOI } & \text { : https://doi.org/10.22146/jpt.43177 }\end{array}$

\title{
The Lodge Maribaya Sebagai Salah Satu Pilihan Destinasi Ekowisata Kabupaten Bandung Barat
}

\author{
Susi Machdalena', Anggraeni Purnama Dewi' ${ }^{2}$ Ypsi Soeria Soemantri ${ }^{3}$ \\ 'Universitas Padjadjaran Bandung \\ machdalena@unpad.ac.id \\ 2Universitas Padjadjaran Bandung \\ purnamaanggraeni@gmail.com \\ 3Universitas Padjadjaran Bandung \\ ypsi.soerias@gmail.com
}

\begin{abstract}
One of the eco-tourism destination in West Bandung Regency is ' The Lodge Maribaya'. It is a nature-based place, surroundings by the hills and pine-trees forest with full of the fresh-air. Besides the beautiful scenery, there are some children playground equipments, such as swings, and slides, there are also some play-equipments for adults, such as Sky-bike or Zip-bike, the equipment for riding the bike on a rope-track up in the sky. Then, a Sky wing is a swing in the edge of a cliff for selfie. The theory of Damanik and Weber (2006) is classified the tourism destination like this is a development of the natural resource to magically attraction, beautiful view, and comfortable fresh-air.
\end{abstract}

Keywords: Eco-tourism, topography, pine-trees forest, hills, playground equipments. 


\section{PENDAHULUAN}

Kegiatan wisata memang sudah menjadi kebutuhan primer di kalangan masyarakat dunia, termasuk masyarakat Indonesia. Tentu pernyataan ini didasarkan pada pengamatan kami selama beberapa tahun terhadap kegiatan wisata. Digelarnya beberapa seminar pariwisata baik di dalam maupun di luar negeri menandakan betapa sektor pariwisata merupakan urusan yang cukup penting untuk diperhatikan dan ditindaklanjuti. The United Nations World Tourism Organization (UNWTO) mengatakan, pada tahun 2013 lalu, tercatat ada sekitar 1, 087 miliar orang turis yang lalu lalang antara negara yang satu dengan yang lainnya. Angka ini pun tumbuh 5\% dibandingkan tahun 2012 lalu. UNWTO pun memprediksi, jumlah turis itu pun akan terus tumbuh dan menyentuh angka 1,8 miliar jiwa pada tahun 2030 mendatang (Nirwandar, 2014: 4).

Dengan prediksi seperti itu, tidak lah mengherankan jika banyak negara, terutama negara berkembang yang semakin tekun dan serius dalam menggarap pasar pariwisata mereka masing-masing, contohnya adalah Indonesia. Tidak bisa dipungkiri bahwa Indonesia memiliki potensi pariwisata yang sangat besar. Indonesia tidak hanya memiliki keindahan alam yang tersebar di seluruh 17 ribu gugusan pulau, tapi juga memiliki kekayaan budaya, bahasa, dan kearifan lokal yang begitu menarik serta beragam sehingga tidak heran jika Indonesia kerap menjadi tujuan wisata di daftar liburan para wisatawan asing, yang jumlahnya terus menunjukkan peningkatan dari tahun ke tahun.

Indonesia sebagai negara kepulauan dengan puluhan ribu pulau dan ratusan suku bangsa tentunya memiliki potensi wisata yang beragam yang selama ini kurang digarap secara optimal dan bahkan tidak dilihat memiliki potensi wisata. Salah satu potensi wisata yang masih perlu dioptimalkan di Indonesia adalah turisme yang berbasis alam (eco based tourism). Wisata yang berbasis alam atau yang popular disebut ekoturisme ini merupakan salah satu kegiatan pariwisata yang berwawasan lingkungan dengan mengutamakan aspek konservasi alam, aspek pemberdayaan sosial budaya ekonomi masyarakat lokal serta aspek pembelajaran dan pendidikan (Nirwandar, 2014: 185).

Menurut The International Ecotourism Society atau TIES (1991), ekowisata adalah perjalanan wisata ke wilayahwilayah alami dalam rangka mengkonservasi atau menyelamatkan lingkungan dan memberi penghidupan penduduk lokal (Nugroho, 2011: 15). Kejenuhan masyarakat terhadap rutinitas harian yang sering kali menyita banyak waktu bahkan seluruh waktunya untuk kegiatan tersebut, tidak sedikit yang menjadikan alam sebagai tempat mereka untuk menterapi jiwa dan raganya agar kembali segar dan pulih serta memiliki semangat untuk memulai aktivitas di kemudian hari. Banyak tempat yang dapat dijadikan tujuan untuk berwisata, salah satunya adalah kota Bandung.

Bandung merupakan salah satu kota di Indonesia yang tidak pernah sepi dari kegiatan pariwisata. Selain karena faktor cuaca yang sejuk dan pemandangan alamnya yang begitu mempesona, Bandung juga memiliki berbagai macam keunikan hasil kreativitas para pemuda dan masyarakatnya. Misalnya modelmodel pakaian, asesories, dan yang paling menonjol adalah kuliner. Terkait 
dengan kuliner, Bandung tidak pernah lepas dari incaran para wisatawan yang gemar mencicipi aneka ragam jajanan khas Bandung dan berbagai macam masakan tradisional hasil karya masyarakat setempat. Berdasarkan pengamatan kami, Bandung merupakan destinasi wisata yang selalu ramai dikunjungi wisatawan baik lokal maupun mancanegara, baik di hari libur maupun di hari kerja.

Banyaknya destinasi wisata yang tersebar di kota Bandung, menjadikan para konsumennya untuk lebih fokus dan pintar menentukan objek wisata mana yang akan dikunjunginya pada saat liburan. Salah satu objek wisata yang terletak di daerah Bandung Barat yang tidak lepas dari incaran para wisatawan adalah objek wisata The Lodge Maribaya. Kawasan wisata ini terletak di jalan Maribaya No. 149/252 RT 03 RW 15, Babakan Gentong - Cibodas Lembang, Kabupaten Bandung Barat. Kawasan ini memiliki luas areal sekitar tiga hektar dan lokasinya tepat di lereng perbukitan Maribaya Bandung. Kawasan Lembang merupakan kawasan di kota Bandung yang memiliki suhu udara sekitar 18-20 derajat celcius, sehingga tidak mengherankan jika di sekitar kawasan ini tumbuh beraneka ragam bunga-bunga yang indah dan cantik serta pohonpohon rindang yang terlihat hijau indah di kejauhan.

\section{METODE PENELITIAN}

Metode penelitian yang kami gunakan adalah metode penelitian kualitatif. Metode penelitian kualitatif adalah metode penelitian yang berlandaskan pada filsafat postpositivisme, digunakan untuk meneliti pada kondisi obyek yang alamiah, (sebagai lawannya adalah eksperimen) dimana peneliti sebagai instrument kunci, teknik pengumpulan data dilakukan secara triangulasi (gabungan), analisis data bersifat induktif (kualitatif), dan hasil penelitian kualitatif lebih menekankan makna daripada generalisasi (Sugiyono, 2014: 13-14). Selain itu, metode penelitian kualitatif dapat didefinisikan sebagai metode penelitian Ilmu-IImu Sosial yang mengumpulkan dan menganalisis data berupa kata-kata (lisan mau pun tulisan) dan perbuatan-perbuatan manusia serta peneliti tidak berusaha menghitung atau menguantifikasikan data kualitatif yang telah diperoleh dan dengan demikian tidak menganalisis angka-angka (Afrizal, 2014: 13).

Berdasarkan pengertian metode penelitian kualitatif tersebut, maka dilakukan langkah-langkah sebagi berikut. Studi pustaka atau literatur dalam melakukan penelitian. Beberapa buku referensi terkait pariwisata dan destinasi wisata The Lodge Maribaya kami jadikan acuan dalam penelitian ini. Langkah selanjutnya adalah observasi atau pengamatan langsung kami lakukan dengan kunjungan ke destinasi tersebut. Langkah kemudian adalah wawancara mendalam dengan beberapa petugas di destinasi tersebut turut melengkapi data-data yang kami perlukan dalam penelitian ini. Tidak jarang kami pun melakukan tanya jawab dengan beberapa wisatawan yang mengunjungi destinasi tersebut.

Hasilnya, kami memperoleh informasi bahwa sebagian besar wisatawan yang mengunjungi destinasi wisata tersebut berasal dari luar kota Bandung dan mereka mengunjunginya pada saat hari libur bersama keluarga. Selain itu, sebagian besar wisatawan yang mengunjungi The Lodge Maribaya mengatakan bahwa mereka 
memperoleh informasi mengenai destinasi ini adalah melalui media internet. Para wisatawan melakukan pencarian informasi mengenai destinasi wisata kota Bandung yang dapat mereka kunjungi beberapa waktu sebelum mereka memutuskan untuk berwisata ke Bandung. Ada juga diantara mereka yang memperoleh informasi destinasi ini berdasarkan promosi dari mulut ke mulut yang mereka terima dari kerabat atau sanak saudaranya.

\section{HASIL DAN PEMBAHASAN}

The Lodge Maribaya merupakan destinasi wisata popular pada saat ini yang menampilkan beragam keunggulan dari wahana permainannya dengan sentuhan konsep alam dan memanfaatkan keindahan sekitar untuk dijadikan tempat-tempat indah mengabadikan suasana liburan keluarga. Artinya, destinasi ini telah dikemas sedemikian rupa sehingga sangat menarik minat para pengunjungnya untuk berfoto di beberapa titik yang indah.

Sesuai dengan pernyataan Damanik dan Weber (2006: 2), bahwa sumber daya alam yang dapat dikembangkan menjadi atraksi wisata alam adalah: (1) keajaiban dan keindahan alam (topografi), (2) keragaman flora, (3) keragaman fauna, (4) kehidupan satwa liar, (5) vegetasi alam, (6) ekosistem yang belum terjamah manusia, (7) rekreasi perairan (danau, sungai, air terjun, pantai), (8) lintas alam (trekking, rafting, dan lainlain), (9) objek megalitik, (10) suhu dan kelembaban udara yang nyaman, (11) curah hujan yang normal, dan lain sebagainya. Berdasarkan pernyataan tersebut, maka kami memahami bahwa destinasi wisata The Lodge Maribaya merupakan destinasi wisata yang merupakan pengembangan dari sumber daya alam menjadi atraksi wisata dengan ciri-ciri memiliki keajaiban dan keindahan alam (topografi). Hal ini dapat kami lihat dari kawasan wisata The Lodge Maribaya yang sepenuhnya menampilkan keindahan alam. Hijaunya hutan pinus di deretan menuju kawasan wisata ini begitu indah dan selalu mengundang decak kagum para pengunjungnya.

Suhu dan kelembaban udara yang nyaman di kawasan The Lodge Maribaya ini merupakan salah satu daya tarik bagi para wisatawan yang ingin menikmati udara yang sejuk setelah lelah dari rutinitas harian di ibu kota yang memiliki suhu udara yang panas. Kami dapat melihat betapa banyak wisatawan baik lokal maupun mancanegara yang mengunjungi tempat ini untuk sekedar menghirup udara yang sejuk sambil menikmati minuman panas yang ditawarkan di area kuliner. Para wisatawan memanfaatkan suasana seperti itu untuk berbincang-bincang bersama keluarga yang mungkin sudah sulit untuk dilakukan di hari-hari kerja. Turunnya kabut yang menutupi pepohonan hijau yang rindang turut menambah keindahan pemandangan sekitar terutama pada saat hujan turun.

Kawasan The Lodge Maribaya merupakan kawasan yang cukup menerima air hujan. Hal ini dapat terlihat pula dari suhu udara yang sejuk dan lembab, tanahnya yang gembur yang menjadikan tanaman begitu mudah tumbuh subur di kawasan ini. Ketika musim penghujan tiba, destinasi wisata The Lodge Maribaya tetap tidak kehilangan pengunjungnya. Hal ini dapat kami buktikan pada saat kami mengunjungi destinasi tersebut di pertengahan bulan Oktober dan Desember yang bertepatan dengan musim hujan. Derasnya hujan yang turun di sekitar kawasan ini tetap membuat arus lalu lintas berjalan sangat ramai 
dikarenakan padatnya wisatawan yang mengunjungi destinasi ini. Padahal kami ke sana di hari kerja bukan di hari libur. Beberapa bis dengan nomor polisi dari luar pulau Jawa memenuhi area parkir utama, begitu pun dengan mobil-mobil kecil yang sangat padat memenuhi beberapa area parkir. Tidak sedikit pula para wisatawan lokal yang mengunjungi destinasi wisata ini dengan mengendarai kendaraan umum ataupun sepeda motor. Wisatawan yang datang berasal dari berbagai kalangan, dari yang muda sampai yang tua, para pekerja kantoran yang melakukan wisata bersama, kelompok pelajar, sampai wisatawan mancanegara, di antaranya wisatawan yang berasal dari Malaysia, Singapur, Cina dan India.

Lokasi strategis dari destinasi wisata The Lodge Maribaya menjadikan perjalanan wisata begitu menyenangkan. Wisatawan dapat mengunjungi beberapa destinasi wisata sebelum pada akhirnya tiba di The Lodge Maribaya, atau perjalanan sebaliknya. Beberapa destinasi wisata yang dapat dikunjungi dalam rute perjalanan ini di antaranya adalah Floating Market, Kampung Gajah, Tangkuban Perahu, Air Panas Ciater, Rumah Bunga Rizal, De Ranch, dan beberapa pilihan rumah makan seperti Kampung Daun, Sapu Lidi, dan Mang Engking. Wisata kuliner ini turut memperkaya wawasan para wisatawan akan makanan khas tradisional dan budaya Sunda. Di rumah makan ini disuguhkan suasana alam yang indah dengan balutan budaya khas Sunda, dari mulai bentuk rumah makan yang terdiri dari bale bale yang terbuat dari bamboo atau kayu dan rotan, perlengkapan makan dari bahan kayu, musik kecapi suling yang merupakan ciri khas kesenian Sunda, serta aneka ragam masakan tradisional khas Sunda yang dihidangkan oleh para penyaji yang memakai pakaian khas Sunda, yaitu pakaian kebaya untuk wanita dan pakaian pangsi untuk kaum pria nya. Suasana seperti ini memberikan nuansa berbeda bagi para wisatawan yang sebagian besar berasal dari luar kota. Dalam rute perjalanan seperti ini, wisatawan juga dapat mengunjungi Rumah Batik Lembang yang merupakan salah satu toko souvenir yang di dalamnya menyajikan proses membatik, sehingga para wisatawan memperoleh ilmu membatik dari perjalanan wisata ini, juga menyuguhkan beragam batik yang dapat dibeli di tokonya.

Berdasarkan pengamatan dan informasi yang kami terima dari wisatawan yang kami temui di destinasi tersebut, kami menyimpulkan bahwa kini para wisatawan mulai merapikan agenda perjalanan mereka dengan cara memilih beberapa destinasi wisata yang mungkin dapat dikunjungi dalam satu hari penuh. Hal ini dimaksudkan agar kegiatan liburan mereka dapat berjalan efisien dengan harga yang terjangkau. Adapun destinasi wisata yang dikunjungi kami dalam satu hari tersebut adalah The Lodge Maribaya, Rumah Bunga Rizal, Rumah Batik Lembang, De Ranch dan rumah makan Mang Engking. Perjalanan wisata seperti itu sudah menghabiskan waktu seharian, dari pagi hari sampai sore hari.

Terkait dengan destinasi ini, sebagian besar wisatawan mengatakan bahwa mereka mengunjungi The Lodge Maribaya sebagai tujuan destinasi utama mereka selama berlibur di Bandung. Mereka memperoleh informasi terkait destinasi ini berdasarkan pencarian destinasi wisata kota Bandung melalui media internet dan juga berdasarkan promosi dari mulut ke mulut yang 
mereka dapatkan dari kerabat dan sanak saudara. Hal ini disebabkan karena The Lodge Maribaya merupakan destinasi wisata kabupaten Bandung Barat yang terbilang cukup muda.

Padatnya kegiatan wisata di kawasan Lembang membuat para pengunjungnya berpikir ulang untuk berwisata di hari libur, yaitu Sabtu dan Minggu. Banyak di antara wisatawan yang pada akhirnya memilih jam kerja untuk mengunjungi The Lodge Maribaya, yaitu hari Senin sampai Kamis. Dengan pemikiran seperti itu, maka ketika kami megunjungi destinasi tersebut pada hari Kamis, kepadatan arus lalu lintas dan ramainya pengunjung tidak dapat dihindarkan. Berdasarkan hal tersebut, maka kami menyimpulkan bahwa pada akhirnya, kawasan Lembang selalu menjadi incaran para wisatawan baik lokal maupun mancanegara di setiap harinya. Artinya, tidak ada lagi pembeda yang signifikan antara hari libur dan hari kerja. Pemahaman seperti ini didukung pula oleh datangnya sekelompok wisatawan yang ternyata mereka adalah rekan kerja satu kantor yang berasal dari Jakarta. Berdasarkan wawancara singkat, mereka memilih untuk wisata di hari kerja dengan tujuan menghindari kemacetan lalu lintas dan agar dapat menikmati keindahan The Lodge Maribaya tanpa berdesak-desakan dan dapat berfoto dengan puas di beberapa tempat yang indah. Namun hal tersebut ternyata tidak dapat terwujud dikarenakan padatnya pengunjung yang berasal dari beberapa daerah.

Terjangkaunya harga tiket masuk destinasi wisata ini turut mendukung padatnya wisatawan yang mengunjungi The Lodge Maribaya. Harga tiket masuk pada hari kerja yaitu Rp 20.000 per orang dan pada akhir pekan Sabtu dan
Minggu yaitu Rp 25.000 per orang serta pada hari libur nasional yaitu Rp 35.000 per orang merupakan harga tiket masuk yang terjangkau oleh berbagai kalangan. Begitupun dengan berbagai wahana seperti sky bike, sky wing, balon udara dan gantole yang kisaran harga tiketnya Rp 20.000 per orang menjadikan destinasi ini sebagai destinasi popular yang banyak diincar oleh wisatawan.

Untuk mengunjungi The Lodge Maribaya ini diperlukan persiapan-persiapan tertentu. Persiapan-persiapan ini adalah 1) alangkah baiknya wisatawan datang pagi-pagi sekitar pukul 08.00 dengan tujuan untuk memperoleh tempat parkir kendaraan yang dekat dengan lokasi wisata, hal ini disebabkan tempat parkir yang dekat ke lokasi tidak banyak dapat menampung kendaraan, sehingga kendaraan diparkir pada jarak yang agak jauh dari lokasi wisata, kira-kira berjarak $2 \mathrm{Km}$. Pihak pengelola memberikan fasilitas bagi pengunjung yang memarkir mobil mereka di tempat ini. Pengelola menyediakan mobil-mobil angkutan secara gratis bagi pengunjung baik pada saat akan menuju ke lokasi maupun pada saat kembali ke tempat parkir kendaraan mereka; 2) wisatawan perlu membawa payung atau jas hujan karena hujan di daerah ini kerap kali turun; 3) pengunjung perlu menggunakan sepatu yang nyaman untuk berjalan di area wisata, karena tempat ini selain berbukitbukit dan memiliki banyak anak tangga juga jalanannya licin; 4) wisatawan membawa camera untuk mengabadikan kegiatan mereka di tempat itu.

Adanya fasilitas angkutan ini memberikan kesempatan untuk penduduk setempat yang memiliki mobil untuk ikut serta dalam memberikan fasisitas angkutan bagi wisatawan. Mobil-mobil ini bukan mobil baru dan 
bagus tetapi mobil ini adalah mobil-mobil yang dulunya digunakan untuk angkutan umum dan saat ini mobil-mobil tersebut sudah sulit digunakan untuk jarak yang jauh sebagai angkutan umum. Pengelola The Lodge Maribaya bekerjasama dengan penduduk setempat untuk memanfaatkan mobil-mobil tua mereka untuk mengangkut wisatawan. Hal ini sangat membantu para wisatawan yang berkunjung ke tempat itu. Selain itu, wisatawan merasa aman dengan sistem angkutan seperti ini karena bila tidak diatur sedemikian rupa maka akan terjadi keributan di antara para pengemudi. Mereka akan berebut mengangkut wisatawan dengan memasang tarif angkutan dengan harga tinggi serta akan menampung penumpang dengan daya tampung yang melebihi kapasitas mobil-mobil tersebut.

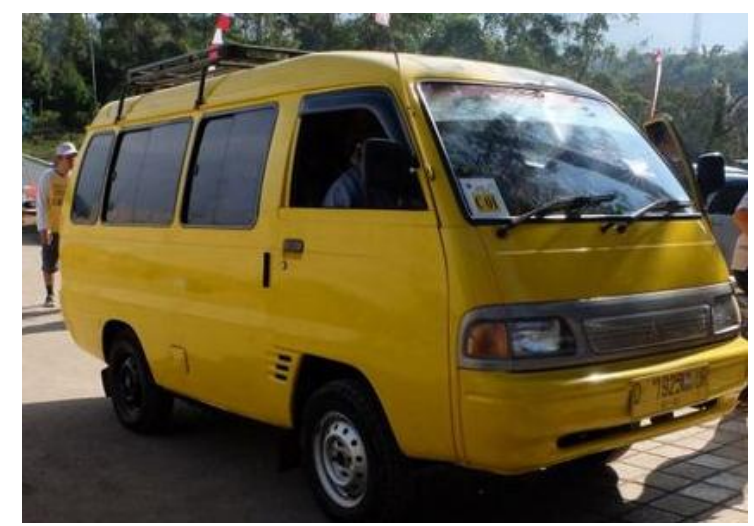

Gambar 1 Foto Angkutan yang membawa wisatawan menuju lokasi

Sumber: dokumentasi pribadi

Di sepanjang jalan menuju lokasi terdapat kios-kios yang menjual berbagai macam suvenir serta minuman dan makanan ringan. Berdasarkan pengamatan kami, suvenir-suvenir yang dijual belum mencerminkan suvenirsuvenir yang menjadi ciri khas tempat wisata The Lodge Maribaya dan daerah Kabupaten Bandung Barat. Hal ini perlu dipikirkan dan dikelola dengan baik oleh pihak pengelola daerah wisata tersebut.
The Lodge Maribaya tidak hanya menyuguhkan keindahan alamnya yang masih asri dan murni, tetapi juga menyediakan beragam wahana menarik sebagai daya tarik wisata yang dapat diunggulkan dari destinasi ini. Beberapa wahana tersebut adalah Hot Air Baloon, yaitu balon udara yang dapat mengangkut para wisatawan pada ketinggian sekitar enam meter. Dari atas balon udara ini para wisatawan dapat mengambil foto dengan latar pohon pinus yang rindang. Ketika wisatawan menaiki balon udara ini, maka seolah olah berada di atas pegunungan yang dapat melihat keindahan kawasan The Lodge Maribaya.

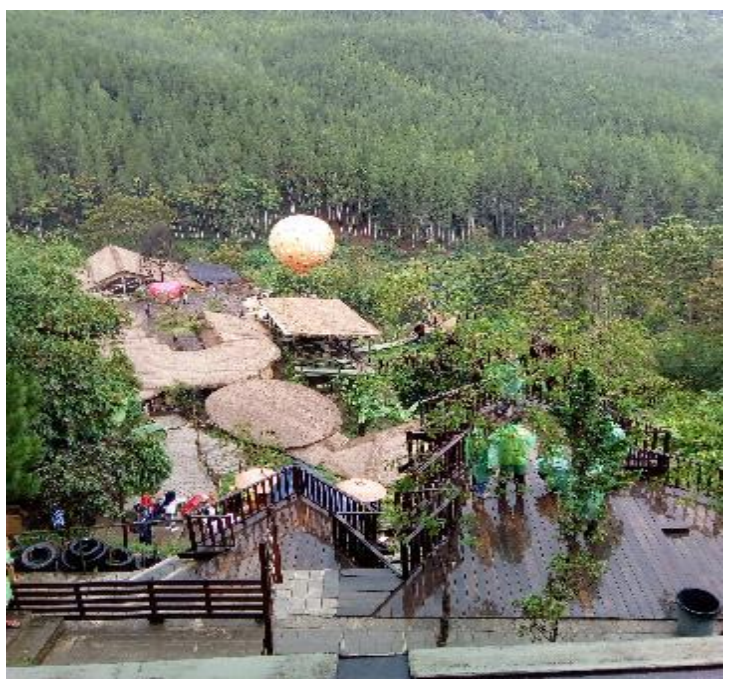

Gambar 2 Foto Hot Air Baloon

Sumber: dokumentasi pribadi

Selain itu, terdapat pula wahana Gantole atau paralayang, yaitu suatu wahana ekstrem yang dapat membawa penumpangnya pada ketinggian udara seperti para penerjun. Bagi para pencinta olah raga ekstrem seperti ini, tentu aktivitas ini dapat diabadikan dengan berfoto ala penerjun. Namun wahana ini tidak se-ekstrem yang dibayangkan, karena paralayang ini hanya diam di tempat. Ada pun tujuan dari wahana ini sesungguhnya hanya untuk pengambilan foto yang bagus. 
Dengan kemasan dan kreativitas pembuatnya, maka seolah olah wahana ini benar-benar terbang melayang layang di udara. Hal inilah yang membuat daya tarik wisatawan mengunjungi The Lodge Maribaya.

Berdasarkan pengamatan kami, wahana yang terlihat cukup padat dikunjungi wisatawan adalah Sky Bike atau Zip Bike, yaitu suatu wahana yang menyuguhkan bersepeda di atas trek seutas tali yang berada di atas jurang. Wisatawan dapat menikmati wahana ini dengan cara menaiki sepeda seolah olah sedang bersepeda di atas tali yang di bawahnya adalah jurang. Namun kenyataanya adalah wahana ini sebagai spot atau titik berfoto yang indah dengan gaya bersepeda di udara. Sekalipun tidak mengayuh sepeda seperti halnya bersepeda di jalanan, namun pacuan adrenalin mengiringi aktivitas ini. Hal ini dapat terlihat dengan ketegangan dari para pengunjungnya dan teriakan ketakutan karena berada di ketinggian. Tentu saja hal seperti ini memberikan kesan mendalam bagi para peminatnya.

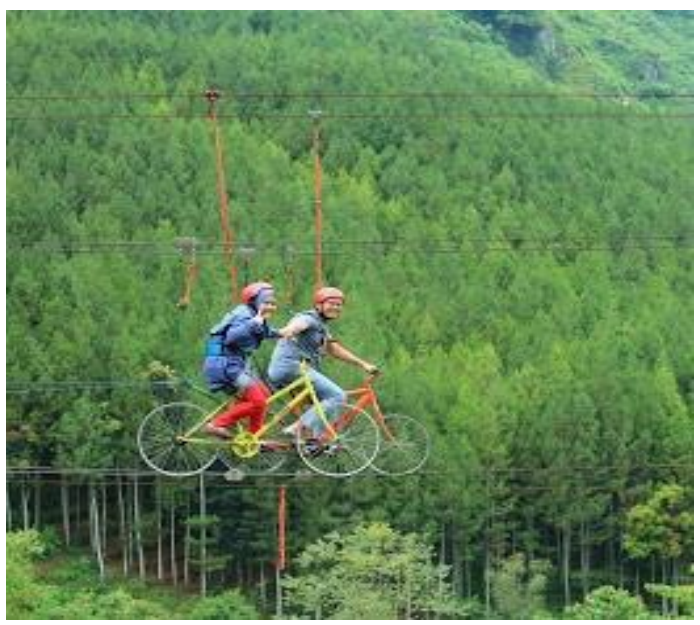

Gambar 3 Foto Sky Bike

Sumber: dokumentasi pribadi

Wahana yang tidak kalah menariknya adalah Sky Wing, yaitu suatu wahana berfoto berupa ayunan di tepi tebing dengan latar pemandangan perbukitan hingga hutan pinus. Ketika wisatawan berfoto di wahana ini, maka seolah olah mereka sedang berayun pada ketinggian di atas bukit.

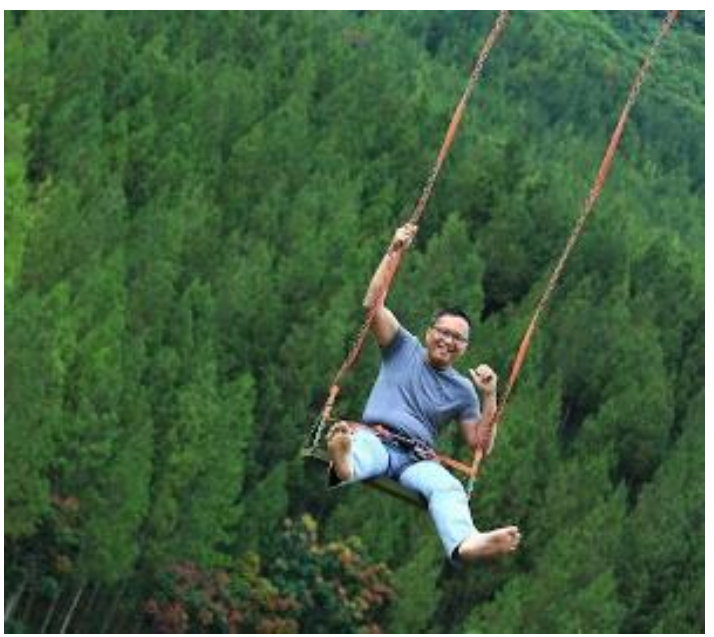

Gambar 4 Foto Sky Wing

Sumber: dokumentasi pribadi

Selain itu, terdapat juga Sky Tree, yaitu wahana berfoto yang menyuguhkan rumah pohon dengan latar pemandangan hutan pinus yang hijau terhampar. Banyak di antara pasangan muda mudi atau suami istri yang menikmati wahana ini. Sederhana namun terlihat sangat megah. Wahana lainnya yang ditawarkan The Lodge Maribaya adalah Bamboo Sky, yaitu suatu wahana yang menyuguhkan pemandangan pepohonan pinus yang sangat indah dan memiliki kesamaan dengan wahana Sky Tree. Bagi wisatawan yang suka dengan suasana bermalam di alam terbuka, maka Glamour Camping merupakan wahana yang tepat untuk dipilih dari banyaknya wahana yang ditawarkan The Lodge Maribaya. Glamour Camping atau disebut juga Glamping merupakan tempat berkemah dengan fasilitas lengkap seperti fasilitas hotel. Para wisatawan yang mengambil wahana ini akan mendapatkan pelayanan seperti halnya di hotel, dari mulai perlengkapan tidur, 
peralatan mandi, dan lain sebagainya. Untuk melengkapi suasana berkemah ini, wisatawan dapat juga memesan api unggun dan kambing guling. Berdasarkan pengamatan kami pada saat kunjungan, sebagian besar wisatawan yang mengambil wahana ini adalah sebuah keluarga, walaupun ada juga yang merupakan pasangan suami istri. Letak toilet yang tidak jauh dari area kemah ini tentu memberi kenyamanan bagi para pengunjungnya. Kebersihan toilet di tempat ini pun begitu diperhatikan. Dengan demikian, maka pemilik destinasi wisata ini telah memperhatikan beberapa sektor dari pariwisata.

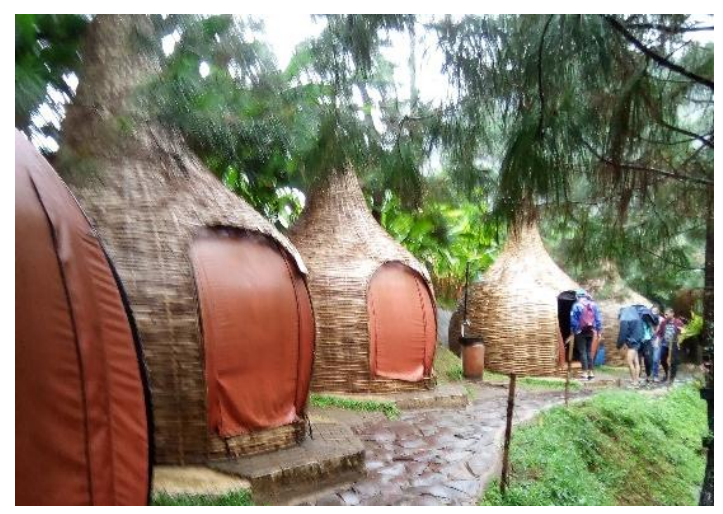

Gambar 6 Foto Glamping

Sumber: dokumentasi pribadi

Sesuai dengan klasifikasi Leiper (1990: 29-30) yang menyatakan bahwa terdapat tujuh sektor utama dalam industri pariwisata, yaitu sektor pemasaran, sektor perhubungan, sektor akomodasi, sektor daya tarik/ atraksi wisata, sektor tour operator, sektor pendukung atau rupa-rupa dan sektor pengkoordinasi atau regulator, maka kami melihat bahwa destinasi wisata The Lodge Maribaya telah memenuhi ketujuh sektor utama dalam industri pariwisata tersebut.

Terkait dengan pemasaran, kami melihat bahwa The Lodge Maribaya telah berhasil dipasarkan dengan baik melalui berbagai media, baik cetak maupun elektronik. Wisatawan yang mencari informasi atas rencananya melakukan perjalanan wisata ke kawasan Lembang melalui media internet, akan dengan mudah menemukan situs The Lodge Maribaya yang di dalamnya memuat berbagai informasi tentang destinasi wisata tersebut. Selain itu, pihak manajemen The Lodge Maribaya pun telah bekerja sama dengan beberapa biro perjalanan wisata, di dalamnya termasuk dengan tempat penyewaan mobil yang menjadi sarana untuk mempromosikan objek wisata tersebut kepada para wisatawan. Yang tidak kalah pentingnya dari metode pemasaran ini adalah informasi dari mulut ke mulut. Berdasarkan informasi yang kami terima dari beberapa wisatawan, banyak diantara mereka yang mengetahui destinasi wisata The Lodge Maribaya dari kerabatnya yang pernah mengunjunginya. Pada mulanya banyak wisatawan yang akan berwisata ke kawasan Lembang dengan objek tujuan adalah Tangkuban Perahu, Air Panas Ciater dan Floating Market. Namun ketika mereka mendapatkan informasi dari kerabatnya, maka tidak sedikit yang mengalihkan tujuan wisata mereka ke The Lodge Maribaya.

Sarana perhubungan atau transportasi untuk menuju The Lodge Maribaya tentu dapat ditempuh dengan beberapa cara. Untuk wisatawan mancanegara dan wisatawan luar pulau, mereka dapat menggunakan mobil sewa yang disediakan oleh pihak hotel tempat mereka menginap. Mereka dapat menyewa mobil dengan beraneka ragam pilihan waktu, mulai dari sewa 4 jam sampai 24 jam. Dengan model sewa kendaraan seperti ini, maka memudahkan wisatawan untuk mengunjungi beberapa objek wisata 
yang tentunya tidak begitu jauh dari kawasan Lembang. Hal ini dilakukan dengan harapan agar wisatawan dapat menikmati masing-masing objek wisata dengan puas dan tidak memakan waktu yang panjang untuk perjalanannya. Kami melihat pula banyak bis luar kota yang parkir di The Lodge Maribaya yang penumpangnya adalah para pekerja kantor yang sedang berwisata dan para pelajar yang sedang berlibur bersama. Artinya, sarana transportasi untuk menuju destinasi wisata ini tidaklah sulit. Selain itu, bagi wisatawan yang bertempat tinggal di kawasan tersebut dapat menggunakan kendaraan umum untuk menuju lokasi. Adanya sarana angkut wisatawan dari area parkir menuju objek wisata merupakan salah satu bentuk pelayanan yang diberikan pihak The Lodge Maribaya kepada para wisatawan.

Sektor akomodasi merupakan salah satu sektor yang sangat penting dalam kegiatan pariwisata. Kami memandang bahwa The Lodge Maribaya telah memenuhi sektor ini. Kawasan strategis ini terletak tidak jauh dari beberapa tempat penginapan, seperti Sari Ater Hotel, Imah Seniman Resort, Moscato Hotel \& Café, Alam Permai Hotel dan masih banyak lagi lainnya. Banyaknya penginapan sekitar The Lodge Maribaya tentu memberikan kemudahan bagi para wisatawan mancanegara ataupun wisatawan yang datang dari tempat jauh untuk menuju destinasi tersebut. Selain itu, wahana berkemah yang ditawarkan oleh destinasi wisata ini selain berfungsi sebagai wahana unik yang nyaman, juga sebagai kemudahan akomodasi bagi para wistaawan yang ingin menikmati alam asri The Lodge Maribaya dengan lebih lama. $\mathrm{Di}$ samping masalah penginapan, akomodasi di bidang makanan dan minuman atau food and beverage, merupakan sektor utama dalam kegiatan pariwisata. Tentu tidak bisa dihindarkan bahwa kebutuhan akan makanan dan minuman ini merupakan kebutuhan primer dari semua wisatawan.

The Lodge Maribaya telah memiliki beberapa area makanan dan minuman yang disajikan dengan nuansa Sunda yang tidak melepaskan unsur alam. Para wisatawan dimanjakan untuk menikmati hidangan makan siang di sebuah restoran dengan pemandangan menghadap ke hutan pinus. Di area makan ini terdapat tulisan larangan merokok. Hal ini memberikan banyak manfaat bagi para pengunjungnya. Selain untuk memberikan kenyamanan bagi para wisatawan yang tidak merokok dan tidak menyukai bau rokok, juga hal ini dilakukan untuk menjaga kebersihan lingkungan dan kesejukan udara alam Lembang yang dingin. Restoran Omah Bamboo di destinasi wisata ini menyuguhkan makanan khas Sunda. Dari namanya Omah Bamboo, mebel di restoran ini terbuat dari bahan bamboo, rotan dan kayu. Meja, kursi, hiasan, panggung pertunjukan semuanya terbuat dari bamboo, rotan dan kayu. Ada pula kursi warna warni yang disediakan untuk para pengunjung yang melengkapi suasana indah dan hangat di restoran ini. Makanan yang disajikan adalah masakan khas Sunda, diantaranya adalah nasi putih, oseng kangkung, tahu goreng, tempe goreng, gepuk, udang asam manis, ikan mas goreng, pepes ayam, dan masih banyak lagi yang lainnya. Minuman panas khas kota Bandung tidak lepas dari incaran para wisatawan, seperti bandrek, bajigur, kopi dan teh panas tawar.

Terkait dengan sektor daya tarik atau atraksi wisata, kami melihat bahwa The 
Lodge Maribaya telah memenuhi unsur ini. Sebagian besar wisatawan mengunjungi destinasi ini adalah untuk berfoto di spot tertentu yang memberikan kesan luar biasa, seperti berfoto dengan menggunakan sepeda di udara, berfoto di balon udara, berfoto di atas ayunan kayu dengan latar hutan pinus, yang semuanya itu memberikan kesan luar biasa dan sangat cocok untuk kenang-kenangan. Hal ini tentu merupakan keunggulan atau menjadi daya tarik tersendiri dari The Lodge Maribaya. Selain itu, bagi para wisatawan yang menyukai seni tari atau sendratari, setiap hari Sabtu malam digelar sendratari Sangkuriang di panggung restoran Omah Bamboo. Hal ini merupakan daya tarik tersendiri bagi para wisatawan yang ingin menikmati tarian dan mengetahui legenda Sangkuriang yang menjadi cikal bakal terbentuknya Gunung Tangkuban Perahu.

Adanya pagelaran budaya seperti ini tentu memiliki beberapa pengaruh positif. Pertama, para wisatawan baik lokal maupun mancanegara dapat menikmati salah satu seni tari yang berasal dari tanah Pasundan. Mereka menjadi tahu legenda asal terbentuknya Gunung Tangkuban Perahu yang merupakan kekayaan folklor daerah Jawa Barat, khususnya kota Bandung. Artinya, pihak manajemen selain menyuguhkan keindahan sendratari, juga telah memperkenalkan salah satu budaya tanah Pasundan. Yang ke dua adalah, para penari yang merupakan penduduk asli daerah Cibodas, Lembang tersebut memiliki aktivitas atau kegiatan setiap malam minggu yang juga menjadi salah satu cara untuk mendapatkan uang dari hasil kegiatannya tersebut. Artinya, sumber daya manusia di sekitar destinasi wisata dioptimalkan dengan baik.
Sektor lainnya yang tak kalah penting adalah sektor tour operator atau penyedia paket wisata. Sektor yang satu ini memiliki peranan penting dalam keikutsertaannya mempromosikan suatu destinasi wisata. Ketika wisatawan menggunakan jasa pelayanan penyedia paket wisata, maka secara otomatis mereka akan ditawarkan berbagai macam pilihan paket wisata, yang salah satunya adalah destinasi wisata The Lodge Maribaya. Sebuah biro penyedia paket wisata tidak begitu saja mempromosikan suatu destinasi jika tanpa kerjasama dan kesepakatan. Dalam hal ini, artinya hubungan yang dibina antara penyedia paket wisata dan pihak destinasi wisata harus berjalan baik dan selaras.

Dalam kegiatan pariwisata, sektor pendukung seperti bank, rumah sakit, toko souvenir, restoran, kartu kredit dan lainnya menjadi hal yang sangat penting dalam penunjang keberlangsungan kegiatan wisata. Tidak sedikit wisatawan mancanegara yang datang ke suatu destinasi wisata masih membawa mata uang asing sebagai alat pembayaran. Oleh karena itu, peranan money changer atau tempat penukaran mata uang asing menjadi satu sektor yang sangat penting. Dari sini pula penyedia jasa penukaran mata uang asing memperoleh keuntungan. Cuaca yang berbeda antara suatu destinasi wisata dengan daerah asal wisatawan, menjadi peluang munculnya berbagai macam gangguan kesehatan. Di sinilah peranan rumah sakit atau balai pengobatan memberikan kontribusinya bagi keberlangsungan pariwisata.

Sudah menjadi kebiasaan para wisatawan, ketika mereka akan kembali ke daerah asalnya, mereka akan membeli 
buah tangan baik untuk dirinya sendiri ataupun untuk dihadiahkan kepada orang lain. Wisatawan yang baru saja mengunjungi The Lodge Maribaya dapat membeli kain batik, pakaian batik ataupun perlengkapan rumah tangga yang terbuat dari bahan batik di pusat oleh-oleh batik, salah satunya Rumah Batik Lembang. Begitupun bagi pencinta tanaman hias, wisatawan dapat membeli beraneka ragam tanaman hias di kebun bunga, Parongpong, Cihideung, Lembang. Di sini tersedia beraneka bibit bunga yang dapat dibudidayakan di rumah sendiri. Bagi para penyuka bunga anggrek dan tanaman kaktus, wisatawan dapat mampir mengunjungi Rumah Bunga Rizal setelah meninggalkan The Lodge Maribaya. Selain batik dan bunga, masih banyak jenis souvenir yang dapat dibeli di kawasan wisata Lembang ini.

Dari semua sektor utama kegiatan pariwisata, sektor yang tidak dapat diabaikan adalah sektor pengkoordinasi atau regulator. Peranan masyarakat setempat, pemerintah daerah, pemerintah pusat, sampai dengan pihak pengelola pariwisata dunia berperan sangat besar dalam hal ini. Semua pihak terlibat dalam mempromosikan suatu destinasi wisata serta mengatur perjalanannya melalui sektor-sektor terkait seperti perhubungan, transportasi, akomodasi, penyedia jasa wisata dan lainnya.

\section{SIMPULAN DAN SARAN}

Setelah mengunjungi The Lodge Maribaya maka kami berkesimpulan bahwa The Lodge Maribaya telah memenuhi ketujuh sektor utama dalam kegiatan pariwisata. Dengan demikian diharapkan adanya kesinambungan dan keberlanjutan dari jenis-jenis wisata alam lainnya yang dapat mendukung kegiatan wisata.
Bagi pemerintah daerah Lembang khususnya, yang memiliki alam yang masih alami dan udara yang sejuk, diharapkan dapat memotivasi para penduduk sekitar untuk mengoptimalkan lahan yang ada menjadi destinasi wisata berbasis alam yang dapat mendukung kelestarian lingkungan disamping memberikan peluang tamasya bagi para konsumen. Jika hal ini dapat terwujud, maka salah satu masalah besar bangsa yaitu tingginya tingkat pengangguran dapat teratasi dengan baik.

\section{DAFTAR PUSTAKA}

Afrizal. (2014). Metode Penelitian Kualitatif. Jakarta: PT Raja Grafindo Persada.

Damanik, Janianton dan Helmut F. Weber. (2006). Perencanaan Ekowisata: Dari Teori ke Aplikasi. Yogyakarta: C.V Andi Offset.

Leiper, Neil. (1990). Tourism System: An Interdisciplinary Perspective. Department of Management Systems, Business Studies Faculty, Massey University, Palmerston North, New Zealand.

Nirwandar, Sapta. (2014). Building Wow: Indonesia Tourism and Creative Industry. Jakarta: PT Gramedia Pustaka Utama.

Nugroho, Iwan. (2011). Ekowisata dan Pembangunan Berkelanjutan. Yogyakarta: PUSTAKA PELAJAR.

Sugiyono. (2014). Metode Penelitian Kombinasi (Mixed Methods). Bandung: ALFABETA 